\title{
The digestion of protein in young pigs and the utilization of dietary methionine
}

\author{
BY JANE LEIBHOLZ \\ Department of Animal Husbandry, University of Sydney, Camden, \\ New South Wales 2570, Australia
}

(Received 25 July 1983 - Accepted 13 August 1984)

\begin{abstract}
1. Forty pigs between 23 and $51 \mathrm{~d}$ of age were given ad lib. diets containing wheat and one of five protein concentrates: meat meal A, meat meal B, soya-bean meal, milk and lupins (Lupinus augustifolius). Twenty of these pigs were given indigestible markers from 51 to $56 \mathrm{~d}$ of age and were killed at $56 \mathrm{~d}$ of age.

2. The diets containing meat meals $\mathrm{A}$ and $\mathrm{B}$, soya-bean meal and milk contained $2 \cdot 3 \mathrm{~g}$ total methionine $/ \mathrm{kg}$ and the diet containing lupins contained $2 \cdot 1 \mathrm{~g} / \mathrm{kg}$.

3. A further forty pigs of the same age were given the same diets supplemented with $1 \mathrm{~g}$ synthetic methionine $/ \mathrm{kg}$.

4. The weight gains and feed conversion ratios of the pigs given the diets containing $2 \cdot 1-2 \cdot 3 \mathrm{~g}$ methionine and $3 \cdot 1-3 \cdot 3 \mathrm{~g}$ methionine $/ \mathrm{kg}$ were not significantly different.

5. The weight gains of the pigs given lupins $(2.1 \mathrm{~g}$ methionine $/ \mathrm{kg})$ were less than those of the pigs given the diets containing $2 \cdot 3 \mathrm{~g}$ methionine $/ \mathrm{kg}$.

6. The apparent digestibility of dry matter (DM) and nitrogen was less for the diets containing the meat meals $(0.75$ and 0.78 respectively) than for those containing the other protein concentrates $(0.80$ and 0.84$)$.

7. The retention times in the large intestine of the diets containing soya-bean meal and lupins were 965 and $1083 \mathrm{~min}$ which were greater than those of the diets containing the other protein concentrates, mean $732 \mathrm{~min}$.

8. The major site of $\mathrm{N}$ digestion and absorption for the diet containing milk was the area of the small intestine $25-50 \%$ of total length from the pylorus, while for the other protein concentrates the major site was $50-75 \%$ of its total length from the pylorus.

9. The digestion and absorption of $\mathrm{N}$ in the large intestine was less $(3.4 \%)$ for the diet containing milk than for those containing the other protein concentrates $(7 \cdot 5-11 \cdot 3 \%)$.

10. The apparent digestibility of the methionine to the ileum for the five diets ranged from 0.74 to 0.86 while the calculated retention of the apparently-absorbed methionine was 1.00 . It was suggested that methionine digestibility could be used as an indicator of availability.

11. The calculated retention of apparently absorbed $\mathrm{N}$ in the carcass was 0.71 for the pigs given the diet containing milk and $0.51-0.58$ for the pigs given the other diets.
\end{abstract}

Methionine and lysine are often considered to be the first two limiting amino acids in the diets of young pigs. However, recent reviews have concluded that early results in the literature may have been overestimates of the methionine requirement of pigs. For example, the (US) National Research Council (1973) summarized information on the methionine plus cystine requirement of the $5-10 \mathrm{~kg}$ pig as $6.9 \mathrm{~g} / \mathrm{kg}$ diet while by 1979 the recommended level was reduced to $5.6 \mathrm{~g} / \mathrm{kg}$ diet ((US) National Research Council, 1979). In addition to knowledge of the total methionine content of a diet, it is important to know the availability of methionine to the pig from different feedstuffs. It is possible that the large range of published methionine requirements may be partially explained by differences in the availability of methionine.

Studies with lysine have shown availabilities of $0 \cdot 39,0.50$ and 0.88 for cotton-seed meal, meat meal and milk protein respectively (Batterham et al. 1979). However, there is no similar information in the literature on the availability of methionine from these feeds and this was, therefore, the main objective of the present experiment. It is of interest to relate the availability of methionine for growth with its apparent absorption to the ileum; this was a further objective of the present experiment. 
Table 1. Composition $(\mathrm{g} / \mathrm{kg})$ of experimental diets

\begin{tabular}{|c|c|c|c|c|c|}
\hline $\operatorname{Diet}^{*} \ldots$ & 1 & 2 & 3 & 4 & 5 \\
\hline \multicolumn{6}{|l|}{ Ingredients } \\
\hline Wheat & 788 & 737 & 749 & 769 & 560 \\
\hline Meat meal A & 154 & - & - & - & - \\
\hline Meat meal B & - & 225 & - & - & - \\
\hline Soya-bean meal & - & - & 160 & - & - \\
\hline Dried skim milk & - & - & - & 140 & - \\
\hline Lupins (Lupinus augustifolius) & - & - & - & - & 350 \\
\hline Tallow & 20 & 30 & - & - & - \\
\hline Calcium dihydrogen phosphate & - & - & 33 & 30 & 35 \\
\hline Limestone & 30 & - & 50 & 50 & 50 \\
\hline Premix ${ }^{\dagger}$ & 5 & 5 & 5 & 5 & 5 \\
\hline Lysine & 3 & 3 & 3 & $3 \cdot 5$ & - \\
\hline Threonine & - & - & - & $2 \cdot 0$ & - \\
\hline Tryptophan & $0 \cdot 1$ & 0.2 & - & $0 \cdot 1$ & - \\
\hline \multicolumn{6}{|l|}{ Determined chemical composition } \\
\hline Crude protein (nitrogen $\times 6.25$ ) & 181 & 197 & 171 & 156 & 220 \\
\hline Methionine & $2 \cdot 3$ & $2 \cdot 3$ & $2 \cdot 3$ & $2 \cdot 3$ & $2 \cdot 1$ \\
\hline Cystine & $3 \cdot 0$ & $2 \cdot 9$ & $3 \cdot 3$ & 2.9 & $4 \cdot 8$ \\
\hline Lysine & $10 \cdot 1$ & $10 \cdot 0$ & $9 \cdot 9$ & $10 \cdot 5$ & $11 \cdot 3$ \\
\hline Tryptophan & 1.8 & 1.6 & $2 \cdot 2$ & 1.6 & 1.7 \\
\hline Threonine & 5.6 & $5 \cdot 7$ & $6 \cdot 1$ & 5.5 & $6 \cdot 2$ \\
\hline \multicolumn{6}{|l|}{ Calculated analyses } \\
\hline Calcium & $29 \cdot 6$ & $29 \cdot 7$ & $29 \cdot 1$ & $29 \cdot 0$ & $29 \cdot 0$ \\
\hline Phosphorus & $11 \cdot 8$ & $16 \cdot 2$ & $10 \cdot 1$ & $10 \cdot 0$ & 10.0 \\
\hline Digestible energy ( $\mathrm{MJ} / \mathrm{kg}$ dry matter) & 14.8 & 14.8 & $14 \cdot 7$ & $14 \cdot 8$ & $14 \cdot 7$ \\
\hline
\end{tabular}

* Diets 6-10 had the same composition as diets 1-5 respectively, except that each diet was supplemented with $1.0 \mathrm{~g}$ methionine $/ \mathrm{kg}$.

$\dagger$ Added to supply $(\mathrm{mg} / \mathrm{kg}): 1.5$ retinol, 0.025 cholecalciferol, $24 \alpha$-tocopherol, 7 riboflavin, 24 niacin, 12 pantothenic acid, $0 \cdot 12$ biotin, 700 sodium, 100 iron, 10 copper, 30 manganese, 100 zinc, 40 oxytetracycline and 100 butylated hydroxytoluene.

\section{MATERIALS AND METHODS \\ Diets}

Five diets were formulated to contain $2.3 \mathrm{~g}$ methionine $/ \mathrm{kg}$ (Table 1 ) which is about $80 \%$ of the published methionine requirement of pigs ((US) National Research Council, 1979), if it is assumed that $50 \%$ of sulphur amino acids may be provided as cystine ((US) National Research Council, 1979). The diets contained one of five protein concentrates: meat and bone meal A ( $470 \mathrm{~g}$ crude protein (CP; nitrogen $\times 6 \cdot 25) / \mathrm{kg})$, meat and bone meal B $(420 \mathrm{~g}$ $\mathrm{CP} / \mathrm{kg}$ ), soya-bean meal (solvent extracted, $422 \mathrm{~g} \mathrm{CP} / \mathrm{kg}$ ), skim milk (spray dried, $350 \mathrm{~g}$ $\mathrm{CP} / \mathrm{kg}$ ) or dehulled lupins (Lupinus augustifolius cv. Unicrop; $408 \mathrm{~g} \mathrm{CP} / \mathrm{kg}$ ). The CP content of the diets was $156-220 \mathrm{~g} / \mathrm{kg}$, and the (US) National Research Council (1979) requirement of all essential amino acids except the sulphur amino acids was met by the diets. The diets were also made isoenergetic by the addition of tallow. Diets 6-10 had the same composition as diets 1-5 except that each was supplemented with $1 \mathrm{~g}$ DL-methionine $/ \mathrm{kg}$.

\section{Animals and management}

A total of eighty male Large White $\times$ Landrace pigs, in four groups of twenty, were weaned at $20 \mathrm{~d}$ of age and housed in tiered cages in groups of ten for a preliminary period of $3 \mathrm{~d}$.

At $23 \mathrm{~d}$ of age the pigs (average weight $5.9 \mathrm{~kg}$ ) were allocated to the ten experimental diets shown in Table 1 . There was one pig per pen. Randomized block designs were used, with each block consisting of pigs of a similar weight. The first twenty pigs were allocated 
to diets $1-5$ (four per diet), the second twenty to diets $6-10$ (four per diet) and the last two groups (forty pigs) to diets 1-10 (four per diet). The diets were offered ad lib. and water was available from nipple drinkers. Fresh food was offered daily, and the food residues and pigs were weighed weekly. The duration of the experiment was $28 \mathrm{~d}$.

The cages were in a draught-free room maintained at $26^{\circ}$. Artificial lighting was continuous at a low intensity. No mortalities occurred during the experiments.

Faeces were collected on screens above sloping trays, which drained the urine into bottles containing $200 \mathrm{ml}$ hydrochloric acid $(5 \mathrm{~mol} / \mathrm{l})$. The collection period was from 45 to $51 \mathrm{~d}$ of age.

Indigestible marker was sprayed on to the feed given to twenty pigs (diets $1-5$, four pigs per diet) from 51 to $56 \mathrm{~d}$ of age. Feed was restricted to $90 \%$ of the ad lib. intake from 51 to $56 \mathrm{~d}$ and offered hourly. The marker used during this period was ${ }^{103} \mathrm{Ru}$-labelled Tris-(1,10-phenanthroline)-ruthenium (II) chloride and details of the procedures have been described by Wilson \& Leibholz (1981a). The intake of the isotope was approximately $2 \cdot 5 \mu \mathrm{Ci} /$ pig per $\mathrm{d}$.

At $56 \mathrm{~d}$ of age, exactly $15 \mathrm{~min}$ after an hourly feeding, the pigs were anaesthetized by intravenous administration of Surital (sodium thiamylal; Parke Davis \& Co., Sydney). The intestinal tract was removed under these conditions to prevent, as far as possible, the shedding of epithelium into the intestinal lumen. The length of the small intestine was measured and then divided into four equal parts (designated SI 1, SI 2, SI 3 and SI 4). All digesta were rapidly removed from the stomach, small intestines, caecum and colon. The digesta were then weighed and the $\mathrm{pH}$ determined, and stored at $-20^{\circ}$. The carcasses were frozen at $-20^{\circ}$.

\section{Analytical methods}

The frozen carcasses were sawn into pieces and minced through a cutter-grinder fitted with a $5 \mathrm{~mm}$ screen plate, and a subsample freeze dried before analysis. Digesta samples were homogenized and counted in an Auto Gamma Spectrophotometer (Model 5320; Packard Instrument Co. Inc., Ill). Dry matter (DM) was determined using a forced-air oven at $95^{\circ}$. Amino acids in feed and digesta samples were determined using ion-exchange chromatography (TSM Amino Acid AutoAnalyzer; Technicon Equipment Ltd, Sydney) after samples had been oxidized with performic acid and then hydrolysed in $6 \mathrm{M}$-hydrochloric acid for $24 \mathrm{~h}$ at $136^{\circ}$. Total $\mathrm{N}$ was determined by the Kjeldahl method and trichloracetic acid-precipitable $\mathrm{N}$ by the method of Ternouth $e t$ al. (1974). Carcass fat was determined by the Soxhlet method, extracting the samples with light petroleum (b.p. $40-60^{\circ}$ ) for $18 \mathrm{~h}$.

\section{Statistical analysis}

The values were subjected to analysis of variance and least significant differences $(P<0.05)$ were used to compare means statistically (Steel \& Torrie, 1960).

The standard errors were calculated as $\sqrt{ }(\mathrm{EMS} / n)$ where EMS is error mean square and $n$ was 16 for protein source, 40 for methionine supplement and 8 for interaction in Table 2 and 4 in all other tables. The weight-gain values were corrected for differences in feed intake by covariance (Steel \& Torrie, 1960).

\section{RESULTS}

\section{Performance of pigs}

The weight gains of the pigs (Table 2) were not significantly different between the pigs given the diets containing $2 \cdot 1-2 \cdot 3 \mathrm{~g}$ methionine/ $\mathrm{kg}$ and those given diets containing $3 \cdot 1-3 \cdot 3 \mathrm{~g}$ methionine $/ \mathrm{kg}$. The weight gain and feed conversion ratio of the pigs fed on the diets containing $2 \cdot 1-2 \cdot 3 \mathrm{~g}$ methionine/ $\mathrm{kg}$ were higher when milk protein was included than for the other four sources of protein. Also, the weight gain of the pigs fed on the diet containing 
Table 2. The performance of pigs from 23 to $51 \mathrm{~d}$ of age given five protein concentrates to contain $2 \cdot 1-2 \cdot 3$ or $3 \cdot 1-3 \cdot 3 \mathrm{~g}$ methionine $/ \mathrm{kg}$

\begin{tabular}{|c|c|c|c|c|c|c|c|}
\hline \multirow{2}{*}{$\begin{array}{l}\text { Methionine } \\
\text { in diet } \\
\text { ( } \mathrm{g} / \mathrm{kg})\end{array}$} & \multirow{2}{*}{ Protein concentrate } & \multirow{2}{*}{$\begin{array}{l}\text { Wt gain } \\
(\mathrm{g} / \mathrm{d})\end{array}$} & \multirow{2}{*}{$\begin{array}{l}\text { Adjusted } \\
\text { wt gain } \dagger \\
(\mathrm{g} / \mathrm{d})\end{array}$} & \multirow{2}{*}{$\begin{array}{l}\text { Feed } \\
\text { conversion } \\
\text { ratio }\end{array}$} & \multicolumn{2}{|c|}{$\begin{array}{c}\text { Apparent } \\
\text { digestibility }\end{array}$} & \multirow{2}{*}{$\begin{array}{l}\mathrm{N} \\
\text { retentior } \\
(\mathrm{g} / \mathrm{d})\end{array}$} \\
\hline & & & & & Dry matter & Nitrogen & \\
\hline $2 \cdot 3$ & Meat meal A & 266 & 242 & $2 \cdot 02$ & 0.755 & 0.783 & $9 \cdot 21$ \\
\hline $2 \cdot 3$ & Meat meal B & 272 & 246 & 2.08 & 0.741 & 0.784 & 7.69 \\
\hline $2 \cdot 3$ & Soya-bean meal & 259 & 243 & 1.98 & 0.804 & 0.836 & $9 \cdot 54$ \\
\hline $2 \cdot 3$ & Milk & 325 & 313 & 1.75 & 0.821 & 0.846 & 9.99 \\
\hline \multirow[t]{2}{*}{$2 \cdot 1$} & $\begin{array}{l}\text { Lupins } \\
\text { (Lupinus augustifolius) }\end{array}$ & 205 & 240 & 1.92 & 0.793 & $0 \cdot 843$ & $5 \cdot 97$ \\
\hline & Mean & 265 & 256 & 1.95 & 0.783 & 0.818 & $8 \cdot 48$ \\
\hline $3 \cdot 3$ & Meat meal A & 259 & 253 & 1.92 & 0.757 & 0.796 & $9 \cdot 19$ \\
\hline $3 \cdot 3$ & Meat meal B & 264 & 256 & 1.90 & 0.738 & 0.828 & 8.60 \\
\hline $3 \cdot 3$ & Soya-bean meal & 266 & 263 & 1.74 & 0.775 & 0.839 & $9 \cdot 54$ \\
\hline $3 \cdot 3$ & Milk & 271 & 253 & $1 \cdot 85$ & 0.806 & 0.847 & 8.96 \\
\hline \multirow[t]{2}{*}{$3 \cdot 1$} & Lupins & 246 & 263 & $1 \cdot 86$ & 0.796 & 0.853 & 9.79 \\
\hline & Mean & 261 & 258 & $1 \cdot 85$ & $0 \cdot 774$ & 0.833 & $9 \cdot 21$ \\
\hline \multicolumn{8}{|l|}{ SEM due to: } \\
\hline \multirow{2}{*}{\multicolumn{2}{|c|}{$\begin{array}{l}\text { Protein } \\
\text { Methionine in diet }\end{array}$}} & $14 \cdot 8^{*}$ & $14 \cdot 6$ & 0.087 & $0.0079 *$ & $0.0087^{*}$ & $0.52^{*}$ \\
\hline & & $9 \cdot 3$ & $9 \cdot 2$ & 0.055 & 0.0063 & 0.0070 & 0.33 \\
\hline \multicolumn{2}{|c|}{ Protein source $\times$ methionine in diet } & $20 \cdot 7^{*}$ & $20 \cdot 6$ & 0.123 & 0.0112 & 0.0122 & $0.74^{*}$ \\
\hline
\end{tabular}

$* P<0.05$.

$\dagger$ Wt gains adjusted for feed intakes by covariance.

lupins was less than that of pigs fed on diets containing the other protein sources; however, a reanalysis of this diet showed that its methionine content was only $2 \cdot 1 \mathrm{~g} / \mathrm{kg}$ diet in contrast to $2 \cdot 3 \mathrm{~g} / \mathrm{kg}$ diet for the other diets.

After supplementation of the diets with methionine, the differences between the sources of protein were eliminated and the weight gains and feed conversion ratios were similar for all five sources of protein.

The $\mathrm{N}$ retention values (Table 2) showed a lower retention of $\mathrm{N}$ in the pigs given lupins and meat meal B (total methionine content of $2 \cdot 1-2 \cdot 3 \mathrm{~g} / \mathrm{kg}$ diet) than those given the other three sources of protein.

The apparent digestibility of DM and $\mathrm{N}$ was lower for the diets containing meat meal $\mathrm{A}$ and meat meal $\mathrm{B}$ than for the diets containing soya-bean meal, milk or lupins.

\section{Retention time of digesta, $\mathrm{pH}$ and digestion of $\mathrm{DM}$}

The overall retention time of the marker in the digestive tract of the pigs was 1032-1538 min (Table 3). The retention time was greater for the diets containing soya-bean meal and lupins than for the other protein concentrates, and this was due to a longer retention of the marker in the large intestine for the pigs given these two diets.

The average retention time of the marker in the stomach was $147 \mathrm{~min}$, in SI $17.6 \mathrm{~min}$ and in SI $217.9 \mathrm{~min}$ and not significantly different between diets. There were no differences between protein sources. 
Table 3. Mean retention time ( $\mathrm{min})$ of ${ }^{103} \mathrm{Ru}$-labelled Tris-(1,10-phenanthroline)-ruthenium (II) chloride in the gastrointestinal tract of 56-d-old pigs given diets containing five protein concentrates

\begin{tabular}{|c|c|c|c|c|c|c|}
\hline \multirow{2}{*}{$\begin{array}{l}\text { Diet... } \\
\text { Protein concentrate... }\end{array}$} & 1 & 2 & 3 & 4 & 5 & \multirow[b]{2}{*}{ SEM } \\
\hline & $\begin{array}{c}\text { Meat } \\
\text { meal A }\end{array}$ & $\begin{array}{l}\text { Meat } \\
\text { meal B }\end{array}$ & $\begin{array}{c}\text { Soya-bean } \\
\text { meal }\end{array}$ & Milk & Lupins & \\
\hline $\begin{array}{l}\text { Stomach } \\
\text { Small intestinet: }\end{array}$ & 102 & 119 & 197 & 102 & 195 & $43 \cdot 7$ \\
\hline SI 1 & 10 & 7 & 8 & 7 & 5 & $2 \cdot 0$ \\
\hline SI 2 & 28 & 11 & 22 & 24 & 11 & $4 \cdot 6^{*}$ \\
\hline SI 3 & 60 & 36 & 45 & 45 & 36 & $8 \cdot 3$ \\
\hline SI 4 & 51 & 74 & 69 & 63 & 63 & $8 \cdot 3$ \\
\hline Caecum & 116 & 110 & 159 & 133 & 146 & $14 \cdot 6^{*}$ \\
\hline Large intestine & 736 & 676 & 965 & 785 & 1083 & $37 \cdot 9^{*}$ \\
\hline Total & 1103 & 1032 & 1464 & 1159 & 1538 & $87 \cdot 3 *$ \\
\hline
\end{tabular}

$* P<0.05$.

$\dagger$ The length of the small intestine was measured and divided into four equal parts.

Table 4. The pH of the digesta in the stomach, small intestine and caecum of 56-d-old pigs given five protein concentrates

\begin{tabular}{|c|c|c|c|c|c|c|}
\hline \multirow{2}{*}{$\begin{array}{l}\text { Diet... } \\
\text { Protein concentrate... }\end{array}$} & 1 & 2 & 3 & 4 & 5 & \multirow[b]{2}{*}{ SEM } \\
\hline & $\begin{array}{c}\text { Meat } \\
\text { meal A }\end{array}$ & $\begin{array}{c}\text { Meat } \\
\text { meal B }\end{array}$ & $\begin{array}{c}\text { Soya-bean } \\
\text { meal }\end{array}$ & Milk & Lupins & \\
\hline Stomach & $3 \cdot 1$ & $2 \cdot 9$ & 3.9 & $3 \cdot 8$ & $3 \cdot 9$ & 0.47 \\
\hline \multicolumn{7}{|l|}{ Small intestine $\dagger$ : } \\
\hline SI 1 & $6 \cdot 2$ & $6 \cdot 4$ & $6 \cdot 4$ & $6 \cdot 3$ & $6 \cdot 4$ & $0 \cdot 16$ \\
\hline SI 2 & $6 \cdot 4$ & 6.4 & $6 \cdot 7$ & $6 \cdot 8$ & $6 \cdot 8$ & $0.12^{*}$ \\
\hline SI 3 & $7 \cdot 0$ & $7 \cdot 2$ & $7 \cdot 1$ & $7 \cdot 2$ & $7 \cdot 2$ & $0 \cdot 13$ \\
\hline SI 4 & $7 \cdot 1$ & $7 \cdot 4$ & $7 \cdot 4$ & $7 \cdot 3$ & $7 \cdot 4$ & $0 \cdot 17$ \\
\hline Caecum & $6 \cdot 1$ & $6 \cdot 3$ & $6 \cdot 3$ & $6 \cdot 2$ & $6 \cdot 3$ & 0.26 \\
\hline
\end{tabular}

* $P<0.05$.

$\dagger$ The length of the small intestine was measured and divided into four equal parts.

The mean $\mathrm{pH}$ of the stomach was 3.6 and this increased to $7.3 \mathrm{in} \mathrm{SI} 4$ and then reduced to 6.2 in the caecum. There were no differences between the diets (Table 4).

There were small differences in the DM intake of the pigs given the diets containing the five sources of protein, and in all cases the flows of DM through the stomach were not significantly different from the DM intakes (Table 5). The flow of DM through SI 1 ranged from $60 \%$ for the pigs given the milk and lupin diets to $80 \%$ for the pigs given the meat meai B diet. The flow of DM through SI 2, SI 3, SI 4 and the caecum was similar for the pigs given the diets containing all five protein concentrates.

\section{Digestion of $N$}

For the pigs given the diets containing the five protein sources the $\mathbf{N}$ flow through the stomach and SI 1 was similar to the $\mathrm{N}$ intake (Table 6). The flow of $\mathrm{N}$ through SI 2 and SI 3 in the pigs given the milk diet was less than that of the pigs given the other sources 
Table 5. Flows of dry matter $(\mathrm{g} / \mathrm{d})$ through the gastrointestinal tract of 56-d-old pigs

\begin{tabular}{lccccccc}
\hline Diet... & 1 & 2 & 3 & 4 & 5 & \\
\cline { 2 - 6 } & $\begin{array}{c}\text { Meat } \\
\text { meal A }\end{array}$ & $\begin{array}{c}\text { Meat } \\
\text { meal B }\end{array}$ & $\begin{array}{c}\text { Soya-bean } \\
\text { meal }\end{array}$ & Milk & Lupins & SEM \\
\hline Protein concentrate... & 816 & 874 & 781 & 887 & 797 & $96 \cdot 5$ \\
Intake & 816 & 876 & 698 & 870 & 789 & $87 \cdot 2$ \\
Stomach & & & & & & \\
Small intestine $:$ & 638 & 694 & 607 & 533 & 486 & $86 \cdot 4$ \\
SI 1 & 469 & 491 & 447 & 384 & 449 & $52 \cdot 1$ \\
SI 2 & 298 & 367 & 385 & 278 & 362 & $48 \cdot 6$ \\
SI 3 & 298 & 310 & 299 & 276 & 324 & $39 \cdot 3$ \\
SI 4 & 232 & 258 & 218 & 253 & 243 & $37 \cdot 1$ \\
Caecum & 232 & 232 & 151 & 151 & 170 & $25 \cdot 2^{*}$ \\
Large intestine & 200 & 226 & 151 & 151 & 170 & $20 \cdot 8^{*}$ \\
Faeces & & & & & & \\
\hline \hline
\end{tabular}

$* P<0.05$.

$\dagger$ The length of the small intestine was measured and divided into four equal parts.

Table 6. Flows of nitrogen $(\mathrm{g} / \mathrm{d})$ and $N$ digestion in the gastrointestinal tract of 56-d-old pigs given five protein concentrates

\begin{tabular}{|c|c|c|c|c|c|c|}
\hline \multirow{2}{*}{$\begin{array}{l}\text { Diet... } \\
\text { Protein concentrate... }\end{array}$} & 1 & 2 & 3 & 4 & 5 & \multirow[b]{2}{*}{ SEM } \\
\hline & $\begin{array}{c}\text { Meat } \\
\text { meal A }\end{array}$ & $\begin{array}{l}\text { Meat } \\
\text { meal B }\end{array}$ & $\begin{array}{l}\text { Soya-bean } \\
\text { meal }\end{array}$ & Milk & Lupins & \\
\hline \multicolumn{7}{|l|}{ Flow of total N } \\
\hline Intake & 26 & 29 & 23 & 24 & 28 & $3 \cdot 1$ \\
\hline Stomach & 25 & 24 & 19 & 21 & 24 & $2 \cdot 5$ \\
\hline \multicolumn{7}{|l|}{ Small intestine ${ }^{\prime}$} \\
\hline SI 1 & 23 & 22 & 20 & 19 & 26 & $3 \cdot 3$ \\
\hline SI 2 & 18 & 20 & 16 & 10 & 18 & $2 \cdot 1 *$ \\
\hline SI 3 & 9 & 10 & 9 & 7 & 11 & $1 \cdot 3 *$ \\
\hline SI 4 & 8 & 8 & 6 & 6 & 9 & 1.0 \\
\hline Caecum & 8 & 8 & 6 & 5 & 8 & $0.9^{*}$ \\
\hline Large intestine & 6 & 6 & 4 & 4 & 6 & $0.7^{*}$ \\
\hline Faeces & 6 & 6 & 4 & 4 & 4 & $0.6^{*}$ \\
\hline \multicolumn{7}{|c|}{$\begin{array}{l}\text { Percentage of apparent digestion } \\
\text { of } N \text { occurring in }\end{array}$} \\
\hline $\begin{array}{l}\text { Stomach } \\
\text { Small intestinet: }\end{array}$ & 7 & 21 & 18 & 13 & 18 & $4 \cdot 8$ \\
\hline SI 1 & 11 & 9 & 0 & 11 & -8 & 7.0 \\
\hline SI 2 & 25 & 11 & 24 & 43 & 32 & $5.0^{*}$ \\
\hline SI 3 & 42 & 42 & 33 & 17 & 31 & $4 \cdot 8^{*}$ \\
\hline SI 4 & 6 & 9 & 16 & 5 & 9 & $3 \cdot 1 *$ \\
\hline Caecum & 0 & 0 & 0 & 4 & 2 & $3 \cdot 3$ \\
\hline Large intestine & 9 & 8 & 8 & 3 & 11 & $2 \cdot 3^{*}$ \\
\hline
\end{tabular}

$* P<0.05$.

$\dagger$ The length of the small intestine was measured and divided into four equal parts.

of protein. There were no differences in flow of $\mathrm{N}$ through SI 4, caecum and large intestine for the pigs given the five protein sources. In the pigs given the milk diet the major site of $\mathrm{N}$ absorption was SI 2 while for the pigs given meat meals A and B the major site was SI 3. The values for the pigs given soya-bean protein and lupins were intermediate. The $\mathrm{N}$ digested in the large intestine of the pigs given the milk diet was $3.4 \%$ of the total digestion 
Table 7. Trichloracetic acid-precipitable nitrogen in total $N$ in the gastrointestinal tract of 56-d-old pigs given five protein concentrates

\begin{tabular}{lccccccc}
\hline \hline Diet... & 1 & 2 & 3 & 4 & \multicolumn{2}{c}{5} & \\
\cline { 2 - 5 } & $\begin{array}{c}\text { Meat } \\
\text { meal A }\end{array}$ & $\begin{array}{c}\text { Meat } \\
\text { meal B }\end{array}$ & $\begin{array}{c}\text { Soya-bean } \\
\text { meal }\end{array}$ & Milk & Lupins & SEM \\
\hline Protein concentrate... & 0.57 & 0.45 & 0.65 & 0.47 & 0.48 & 0.057 \\
Stomach & & & & & & \\
Small intestine†: & 0.25 & 0.28 & 0.21 & 0.19 & 0.21 & 0.028 \\
SI 1 & 0.30 & 0.31 & 0.25 & 0.16 & 0.21 & $0.030^{*}$ \\
SI 2 & 0.22 & 0.22 & 0.30 & 0.24 & 0.28 & 0.036 \\
SI 3 & 0.46 & 0.36 & 0.41 & 0.36 & 0.37 & 0.034 \\
SI 4 & 0.64 & 0.64 & 0.54 & 0.56 & 0.55 & 0.034 \\
Caecum & 0.62 & 0.59 & 0.55 & 0.53 & 0.53 & 0.033 \\
Large intestine & & & & & & & \\
\hline \hline
\end{tabular}

$* P<0.05$.

$\uparrow$ The length of the small intestine was measured and divided into four equal parts.

Table 8. The absorption of methionine to the ileum (small intestine 4) and its incorporation into body gain in 56-d-old pigs given five protein concentrates

\begin{tabular}{|c|c|c|c|c|c|c|}
\hline \multirow{2}{*}{$\begin{array}{l}\text { Diet... } \\
\text { Protein concentrate... }\end{array}$} & \multirow{2}{*}{$\frac{1}{\text { Meat }}$} & \multirow{2}{*}{$\frac{2}{\text { Meat }_{\text {meal B }}}$} & \multirow{2}{*}{$\frac{3}{\begin{array}{c}\text { Soya-bean } \\
\text { meal }\end{array}}$} & \multirow{2}{*}{$\begin{array}{c}4 \\
\text { Milk }\end{array}$} & \multirow{2}{*}{$\frac{5}{\text { Lupins }}$} & \multirow[b]{2}{*}{ SEM } \\
\hline & & & & & & \\
\hline Intake $(\mathrm{g} / \mathrm{d}), 51-56 \mathrm{~d}$ of age & $2 \cdot 20$ & $2 \cdot 36$ & $2 \cdot 11$ & $2 \cdot 48$ & $2 \cdot 00$ & 0.25 \\
\hline $\begin{array}{l}\text { Apparent flow to small intestine } \\
\text { (SI 4) }(\mathrm{g} / \mathrm{d})\end{array}$ & 0.54 & 0.58 & $0 \cdot 47$ & 0.35 & 0.52 & $0 \cdot 10$ \\
\hline Apparent digestibility & 0.76 & 0.75 & 0.78 & 0.86 & 0.74 & $0.02^{*}-(x-3)$ \\
\hline $\begin{array}{l}\text { Methionine intake }(\mathrm{g} / \mathrm{d}) \text {, } \\
23-51 \mathrm{~d} \text { of age }\end{array}$ & $1 \cdot 23$ & $1 \cdot 30$ & $1 \cdot 18$ & $1 \cdot 31$ & $0 \cdot 83$ & 0.22 \\
\hline $\begin{array}{l}\text { Methionine gain }(\mathrm{g} / \mathrm{d}) \ddagger \\
23-51 \mathrm{~d} \text { of age }\end{array}$ & 0.93 & 0.95 & 0.90 & $1 \cdot 13$ & 0.72 & $0 \cdot 14$ \\
\hline Retention:intake & 0.76 & 0.73 & $0 \cdot 76$ & 0.86 & 0.87 & $0.04^{*}$ \\
\hline Retention:apparent absorption & 0.99 & 0.97 & 0.98 & 1.00 & 1.07 & 0.04 \\
\hline
\end{tabular}

* $P<0.05$.

$\dagger$ The last quarter of the small intestine.

$\ddagger$ Methionine content of weight gain $3.5 \mathrm{~g} / \mathrm{kg}$ (calculated from the means of methionine content of carcass protein (Wilson \& Leibholz, 1981c) and the composition of carcass given in Table 9).

while the values ranged from 7.5 to $11.3 \%$ in the pigs given the other four protein concentrates.

Between 45 and $65 \%$ of the protein was TCA-precipitable in the stomach (Table 7). By the beginning of the small intestine (SI 1), 75-81\% of the $\mathrm{N}$ was TCA-soluble. The protein in the meat meal A and B diets was hydrolysed to a smaller extent in SI 2 than the milk protein. There were no statistical differences between diets in the hydrolysis of protein in the caecum and colon, where $53-64 \%$ of the N was TCA-precipitable.

The apparent digestibility for methionine to SI 4 was $0.74-0.86$ and was significantly greater for milk than the other four protein concentrates (Table 8).

The retention of methionine in weight gain was calculated as follows. The methionine content of the carcass protein was taken as the mean of the values presented by Wilson 
Table 9. Dry matter, crude protein (nitrogen $\times 6.25)$ and fat contents of pig carcasses (56-d-old pigs given five protein concentrates)

\begin{tabular}{|c|c|c|c|c|c|c|}
\hline \multirow{2}{*}{$\begin{array}{l}\text { Diet... } \\
\text { Protein concentrate... }\end{array}$} & 1 & 2 & 3 & 4 & 5 & \multirow[b]{2}{*}{ SEM } \\
\hline & $\begin{array}{c}\text { Meat } \\
\text { meal A }\end{array}$ & $\begin{array}{l}\text { Meat } \\
\text { meal B }\end{array}$ & $\begin{array}{c}\text { Soya-bean } \\
\text { meal }\end{array}$ & Milk & Lupins & \\
\hline Dry matter (g/kg) & 312 & 302 & 331 & 308 & 320 & $9 \cdot 3$ \\
\hline Fat $(\mathrm{g} / \mathrm{kg}$ dry matter) & 380 & 398 & 406 & 383 & 377 & $18 \cdot 1$ \\
\hline Crude protein (g/kg dry matter) & 492 & 474 & 479 & 496 & 503 & 11.9 \\
\hline Protein retention:protein intake & 0.40 & 0.36 & 0.37 & 0.53 & 0.35 & $0.022^{*}$ \\
\hline $\begin{array}{l}\text { Protein retention: apparent protein } \\
\text { absorption to ileum }\end{array}$ & 0.58 & 0.51 & 0.51 & 0.71 & 0.51 & $0.024^{*}$ \\
\hline
\end{tabular}

* $P<0.05$.

\& Leibholz $(1981 c)$. The initial composition of the pigs was also taken from this paper and the final composition of pigs is shown in Table 9 . From these values the methionine content of the live-weight gain was estimated to be $3.5 \mathrm{~g} / \mathrm{kg}$.

The apparent digestibility of methionine to the ileum was calculated for pigs between 51 and $56 \mathrm{~d}$ of age. This digestibility value was applied to the weight gains of the pigs over the whole experiment (23-51 d of age) in the calculation of the retention of dietary methionine (Table 8). Using this value, the apparent retention of methionine in the weight gain was similar to its absorption to the ileum.

\section{Carcass values}

The carcass values in Table 9 show that there was no difference in chemical composition of the carcasses of the pigs given the five protein concentrates. It was calculated that the efficiency of retention of dietary protein in the carcass was greater for the milk diet than for the other four diets largely due to a lower protein content in this diet than in the other four diets.

\section{DISCUSSION}

Five protein concentrates were compared on an equal total methionine basis in diets calculated to supply about $80 \%$ of the requirement for methionine recommended by the (US) National Research Council (1979). Approximately half the methionine in each diet came from the wheat in the diets. Each diet was also supplemented with free methionine to verify that methionine was the first limiting amino acid. The performance of the pigs fed on diets containing 2.3 and $3.3 \mathrm{~g}$ methionine $/ \mathrm{kg}$ was similar, from which it might be concluded that $2.3 \mathrm{~g}$ total methionine $/ \mathrm{kg}$ diet and $2.9-3.3 \mathrm{~g}$ cystine $/ \mathrm{kg}$ diet was sufficient for pigs 23-51 d of age consuming diets containing wheat with meat meal, milk or soya-bean meal as the protein concentrate. On the other hand, pigs given the diet supplying $2.1 \mathrm{~g}$ methionine $/ \mathrm{kg}$ from lupins grew faster when the diet was supplemented with methionine. This may be explained by a requirement of methionine greater than $2 \cdot 1 \mathrm{~g} / \mathrm{kg}$ or a lower availability of methionine from lupins, or both. It was unfortunate that the methionine content of the diet containing lupins was not the same as that of the diets containing the other protein concentrates. The (US) National Research Council (1979) and Agricultural Research Council (1981) suggested minimum requirements of methionine of 2.8 and $3 \cdot 3 \mathrm{~g} / \mathrm{kg}$ diet respectively, while $2.5 \mathrm{~g} / \mathrm{kg}$ diet was considered adequate by Leibholz (1984).

The apparent digestibility of DM in the whole tract was about $5 \%$ less for the two diets which contained meat meal than for those containing milk. As all protein concentrates 
contributed only about half the CP in the diet, the other half being wheat, the real difference in digestibility between meat meal and milk was probably about $10 \%$.

With suckled pigs, Kidder \& Manners (1968) reported the retention time of digesta through the whole tract as 1400-1800 min while, with commercial diets, Kidder \& Manners (1968) reported a retention time of less than $1400 \mathrm{~min}$. These values are similar to those reported in the present experiment of 1000-1500 min. With purified diets and slightly younger pigs ( 28 v. $56 \mathrm{~d}$ ), retention times of 1500-1600 min were reported by Leibholz (1981, 1982). The retention time in the stomach was about $140 \mathrm{~min}$ in the present experiment which is similar to the values of Kidder et al. (1961). Kidder \& Manners (1974) reported a retention time of $150 \mathrm{~min}$ for the flow of digesta through the small intestine, while values of $140-150 \mathrm{~min}$ were observed in the present experiment. The small intestine was divided into four equal sections and the results showed an initial rapid rate of flow at the beginning of the small intestine, $10 \mathrm{~min}$ through the first quarter, increasing to $60 \mathrm{~min}$ through the last quarter. The same observations were made by Wilson \& Leibholz (1981 a) and Leibholz $(1981,1982)$. The source of protein in the diets did not influence the retention time of digesta in the small intestine. However, as observed in an earlier experiment (Leibholz, 1981), the retention time of soya-bean meal and lupin diets in the large intestine was greater than that of milk diets. The values for the diets containing meat meal were intermediate. This might be explained by the higher fibre content of soya-bean meal and lupins than of milk and meat meal. Also, the form of the carbohydrate in these protein concentrates differs from that occurring in the milk and meat-meal protein concentrates.

The gastric $\mathrm{pH}$ in the present experiment was 2.9-3.9 with 56-d-old pigs while values of $5 \cdot 0-5 \cdot 5$ were reported for 28 -d-old pigs by Leibholz (1981). This suggests that acid secretion in the stomach might be dependent on the age of the pig rather than diet as the pigs in these two experiments had been weaned for 28 and $21 \mathrm{~d}$ respectively, at the time of the $\mathrm{pH}$ measurements. Hartman et al. (1961) found that both age and diet could influence gastric $\mathrm{pH}$ in the young pig. The gastric $\mathrm{pH}$ of growing pigs varied between 1.3 and 4.8 depending on time after feeding in studies by Lawrence (1970).

The proteins in food are first acted on in the stomach by pepsins. Pig pepsinogens are hydrolysed to pepsin in acid conditions, slowly at pH 6 and rapidly at pH 2 (Ryle, 1960). With gastric $\mathrm{pH}$ of 2.9-3.9 in the present experiment, about half the dietary protein was hydrolysed in the stomach, and the hydrolysis of soya-bean protein tended to be less than that of the other four protein concentrates. By the duodenum, about $80 \%$ of all protein was hydrolysed which is similar to the value obtained by Zebrowska (1973) for 60-kg pigs given soya-bean protein. On the other hand, the soya-bean protein was only $50 \%$ hydrolysed by the duodenum in pigs of $28 \mathrm{~d}$ of age (Leibholz, 1981; Wilson \& Leibholz, $1981 \mathrm{~b}$ ). Thus, the decrease in gastric $\mathrm{pH}$ between 28 and $51 \mathrm{~d}$ of age and the increased pancreatic secretion (Gorrill \& Friend, 1970) appear to have led to a greater hydrolysis of dietary proteins in the stomach and duodenum.

The hydrolysis of the diet containing milk was greater than that of the other protein concentrates in the small intestine, and there was also a greater apparent and true digestion of the diet containing milk, which was similar to our previous observations with milk and soya-bean protein (Wilson \& Leibholz, $1981 \mathrm{~b}$ ).

The apparent digestibility of methionine to the ileum was 0.86 for milk and 0.75 and 0.76 for meat meals A and B respectively, which agrees with the observations of Alimon \& Farrell (1980). The apparent digestibility of methionine was similar to that of $\mathrm{N}$ for milk, soya-bean meal and meat meal but for lupins the digestibility of methionine $(0.74)$ was less than the digestibility of $\mathbf{N}$. However, the weight gains of the pigs given lupins were less than those of pigs given the other four sources of protein so that the retention of absorbed methionine in terms of weight gain was high for all sources of protein.

The methionine composition of the pigs was taken from Wilson \& Leibholz (1981c) but 
is similar to other values in the literature (e.g. Williams et al. 1954; Aumaitre \& Duée, 1974). The amino acid composition of carcass protein was shown not to alter greatly during the growth of the pigs nor does the amino acid composition of the diet markedly affect the amino acid composition of the body (Williams et al. 1954; Aumaitre \& Duée, 1974; Wilson \& Leibholz, $1981 \mathrm{c}$ ). Hence, the methionine content of the body protein estimated in a previous experiment was used in the present study to estimate the retention of absorbed methionine in weight gain.

The apparent digestibility of methionine to the ileum was calculated for pigs between 51 and $56 \mathrm{~d}$ of age. This digestibility value was applied to the weight gains of the pigs over the whole experiment, $23-51 \mathrm{~d}$ of age, in the calculation of the retention of dietary methionine (Table 8).

Both the retention of $\mathrm{N}$ and of individual amino acids in the empty body would be affected by the balance of amino acids in the diet in relation to the amino acid requirement of the animal for maintenance and growth (Solberg et al. 1971). This means that high efficiency of incorporation of an absorbed amino acid into the carcass would indicate that the amino acid may be limiting. In the present experiment, the efficiency of incorporation of apparently absorbed methionine into weight gain was about 1 , which would suggest that methionine was the first limiting amino acid, especially as the overall retention of apparently absorbed $\mathrm{N}$ in the carcass was $0.51-0.71$. The retention of $\mathrm{N}$ from the milk diet was greater than that from the other four protein concentrates which may suggest a better balance of amino acids in the diet containing milk but it is also notable that the $\mathrm{N}$ content of this diet was less than that of the other four diets.

Hodge (1974) found that the retention of digested $\mathrm{N}$ in the 10 to $30-\mathrm{d}$-old pig given a liquid milk diet was $0.50-0.57$, while these values declined to $0.30-0.39$ between 30 and $50 \mathrm{~d}$ of age. Values of $0.72-0.75$ were reported for diets containing milk and $0.55-0.62$ for diets containing soya-bean protein in 7 to 35 -d-old pigs (Wilson \& Leibholz, 1981 c). These values are similar to those of the present experiment for 56 -d-old pigs, 0.67 for milk and 0.48 for soya-bean meal.

The apparent digestibility of methionine to the ileum was 0.86 for milk and 0.75 for meat meal which is similar to the values reported by Alimon \& Farrell (1980). The efficiency of utilization of the absorbed methionine was not statistically different between treatments; thus, it may be suggested that digestibility values may indicate the efficient utilization of dietary methionine under these conditions. The same conclusion was made by Achinewhu $\&$ Hewitt (1979) in studies with rats and chickens.

In summary, it appeared that $2.3 \mathrm{~g}$ total methionine $/ \mathrm{kg}$ diet containing wheat and meat meal, soya-bean meal, milk or lupins was sufficient to meet the requirements for the growth of pigs from 23 to $56 \mathrm{~d}$ of age. However, $2 \cdot 1 \mathrm{~g}$ methionine $/ \mathrm{kg}$ diet from lupins and wheat was not sufficient. The (US) National Research Council (1979) recommends a minimum requirement of $2.8 \mathrm{~g} / \mathrm{kg}$.

The retention of apparently absorbed methionine in weight gain was high for all sources of protein, and there were no differences between the five diets.

The hydrolysis of proteins (TCA solubility) in the stomach and duodenum of pigs at $56 \mathrm{~d}$ of age was greater than those reported for 28 -d-old pigs.

The present study was made possible by the support of the Australian Pig Industry Research Committee. The author is indebted to Pfizer Agricare Pty Ltd for the vitamins and antibiotics, Dr J. Asher and Mr N. Peck for the preparation of the lupins, $\mathrm{Mr}$ R. Wheeler and Miss E. Howard for laboratory assistance and Ms A. Kirby for the statistical analysis of the data. 


\section{REFERENCES}

Achinewhu, S. C. \& Hewitt, D. (1979). British Journal of Nutrition 41, 559-571.

Agricultural Research Council (1981). The Nutrient Requirements of Pigs. Slough: Commonwealth Agricultural Bureaux.

Alimon, A. R. \& Farrell, D. J. (1980). Australian Journal of Agricultural Research 31, 627-635.

Aumaitre, A. \& Duée, P. H. (1974). Annales de Zootechnie 23, 231-241.

Batterham, E. S., Murison, R. D. \& Lewis, C. E. (1979). British Journal of Nutrition 41, 383-391.

Gorrill, A. D. C. \& Friend, D. W. (1970). Canadian Journal of Physiology 48, 745-750.

Hartman, P. A., Hays, V. W., Baker, R. O., Neagle, L. H. \& Catron, D. V. (1961). Journal of Animal Science 20, 114-123.

Hodge, R. W. (1974). British Journal of Nutrition 32, 113-126.

Kidder, D. E. \& Manners, M. J. (1968). Proceedings of the Nutrition Society 27, 46A.

Kidder, D. E. \& Manners, M. J. (1974). Proceedings, 3rd International Pig Veterinary Congress, Lyon L 11, 1-3.

Kidder, D. E., Manners, M. J. \& McCrea, M. R. (1961). Research in Veterinary Science 2, 227-231.

Lawrence, T. L. J. (1970). Animal Production 12, 151-163.

Leibholz, J. (1981). British Journal of Nutrition 46, 59-69.

Leibholz, J. (1982). British Journal of Nutrition 48, 509-517.

Leibholz, J. (1984). Animal Production 39, 125-128.

National Research Council (1973). Nutrient Requirements of Domestic Animals no. 2, Nutrient Requirements of Swine, 7th ed. Washington, DC: National Academy of Sciences.

National Research Council (1979). Nutrient Requirements of Domestic Animals no. 2, Nutrient Requirements of Swine, 8th ed. Washington, DC: National Academy of Sciences.

Ryle, A. P. (1960). Biochemical Journal 75, 145-150.

Solberg, J., Buttery, P. J. \& Boorman, K. N. (1971). British Poultry Science 12, 297-304.

Steel, R. G. D. \& Torrie, J. H. (1960). Principles of Statistics. New York: McGraw-Hill Book Co.

Ternouth, J. H., Roy, J. H. B. \& Siddons, R. C. (1974). British Journal of Nutrition 31, 13-26.

Williams, H. H., Curtin, L. V., Abraham, J., Loosli, J. K. \& Maynard, L. A. (1954). Journal of Biological Chemistry 208, 277-285.

Wilson, R. H. \& Leibholz, J. (1981 a). British Journal of Nutrition 45, 321-336.

Wilson, R. H. \& Leibholz, J. (1981 b). British Journal of Nutrition 45, 337-346.

Wilson, R. H. \& Leibholz, J. (1981 c). British Journal of Nutrition 45, 359-366.

Zebrowska, T. (1973). Roczniki Nauk Rolniczych 95 B, 115-133. 